M.P. Nesterenko, Dr. Sc. (Tech.), Prof., orcid.org/0000-0002-8961-2147,

P. O. Molchanov, Cand. Sc. (Tech.), orcid.org/0000-0001-5335-4281,

V. M. Savyk, Cand. Sc. (Tech.), orcid.org/0000-0002-0706-0589,

M. M. Nesterenko, Cand. Sc. (Tech.), orcid.org/0000-0002-4073-1233
Poltava National Technical Yuri Kondratyuk University, Poltava, Ukraine, e-mail: mpnesterenko@ukr.net; petja_men@ukr.net

\title{
VIBRATION PLATFORM FOR FORMING LARGE-SIZED REINFORCED CONCRETE PRODUCTS
}

Purpose. Development of the mathematical model of the vibration machine for the formation of large-sized massive reinforced concrete products.

Methodology. Theoretical studies were based on the use of the classical theory of mechanical system vibrations, solid media and applied mechanics. For the analysis of mathematical models, analytical and numerical methods with the use of PC were used.

Findings. With the help of the mathematical study on the working body spatial movement, a dynamic model of the vibration platform in the form of a hard body based on elastic support is developed. The vibration platform is driven by three vibration generators, which are switched in pairs in turn after a given operating mode. The system of the electric drive is proposed according to the scheme of simultaneous alternating work of two vibration generators, which combines the positive properties of the classical drive system of vibration machines with improved performance indicators for the formation of large-sized reinforced concrete products. Differential equations were obtained which allow determining the parameters of each vibration generator to provide a given vibration amplitude of the vibration platform.

Originality. The dynamic model of the vibrational stand based on elastic support and driven by three vibrational generators with pairwise alternating of their activation according to the given mode of operation has been obtained.

Practical value. The rational parameters of each of three vibration exciters are determined to ensure the given amplitude of vibration of the vibration plate.

Keywords: vibration generator, vibration platform, debalance, mathematical model, elastic support, concrete mix

Introduction. In the oil and gas industry, the process of well drilling is accompanied by the presence of large volumes of industrial and technological waste in the form of sludge, which is usually stored in the earth reservoir [1,2], which leads to the spread of drilling wastewater and contamination of surface and groundwater, as well fertile soil layer.

Significant improvement of the environmental situation can be achieved by storing drilling waste in large-sized reinforced concrete containers.

It is possible to accelerate the process of building both such structures and objects of other purpose, including housing, to reduce the cost of transportation of reinforced concrete products at the expense of manufacturing massive reinforced concrete products on mobile at construction sites with modern vibroforming equipment, which will allow receiving highquality products with minimal tolerances and fast rates of construction.

Literature review. Quite widespread in the formation of reinforced concrete products has become the use of vibrating equipment with spatial vibrations of the working body [3], developed by Poltava National Technical Yuri Kondratyuk University [3], the improvement of which can be carried out on the basis of analytical studies taking into account the physical and mechanical characteristics of the compacting medium and the determination of the rational parameters of the vibration platform compactor and modes of vibration action.

The spatial variations of the vibration platform compactors are provided with a single vibrator of circular vibrations with a vertical shaft. When rotating the debalance, a compulsive centrifugal force of circular action arises, whose vector rotates in a horizontal plane at an angular velocity. The components of the forces on the axes of the rectangular system of coordinates OXYZ with the beginning in the center of the mass of the vibratory system generate the spatial variations of the moving frame of the vibration platform compactor and the mold es-

(C) Nesterenko M. P., Molchanov P. O., Savyk V. M., Nesterenko M. M., 2019 tablished on it, which with its bottom and sides are transmitted to the concrete mixture, providing its consolidation. In the works $[4,5]$ the analytical studies on the nature of the interaction of phases of "liquid-solid, in particular, the walls of the mold with a concrete mixture with the vertical and horizontal components of the spatial vibrations of the vibration machine with one unbalanced generator of the circular vibrations in the formation of flat reinforced concrete products were carried out. However, these vibrating machines [6, 7] often form thinwalled products with a bulk configuration. The effectiveness of such products molding can be increased by the use of vibration platform compactors, driven by three vibro-generators with pairwise alternate activation of them in a given mode of operation. Rational parameters of vibration platform $[8,9]$ for the formation of large-sized massive reinforced concrete products can be established by mathematical modeling, which allows determining the rational parameters of each of the vibration generator to protect a given vibration amplitude of the vibration platform.

Purpose. The objective of the research in this paper is to develop a mathematical model of the vibration platform for the formation of large-sized massive reinforced concrete products, driven by three vibration generators with their pairwise alternate activation according to a given operating mode in order to establish the rational parameters of each vibration generator for providing a given amplitude of the platform vibrations.

Results. Application for concrete mix compaction of vibrating machines with spatial vibrations of the working body is effective for a number of products and has several advantages, which are, first of all, in obtaining even-ended elements of massive reinforced concrete products. Special attention is paid to vibrating machines with several vibro-generators, since they allow obtaining different modes of vibration by changing the direction of rotation of the unbalanced shafts [8]. For the improvement of concrete mix compaction conditions during the formation of large-sized products, a vibration platform with a load capacity of 60 tons with a variable mode of the working 
body vibration was developed in Poltava National Technical Yuri Kondratyuk University. Structurally, the vibration platform (Fig. 1) consists of the following elements: a movable frame 1 , elastic rubber and metal supports 2 , vibro-generators with a vertical arrangement of shafts 3 , an engine sub-frame 4 , an electric motor 5 , a base plate 6 , and a reversing electric motor 7. Vibrations in the moving frame of the vibration platform are provided by unbalanced vibration generators with vertical shafts. During the formation of a reinforced concrete product, the direction of working body vibrations alternately changes in time according to the prescribed compaction regime. Two diagonally located vibration generators have a motor drive, sheave of which rotate towards each other, and the third vibration generator has a reversing electric motor drive. In this way, the direction of vibration of the vibration platform working body and the modes of reinforced concrete elements compaction are ensured. The vibration platform at each mode of compaction is $20-30 \mathrm{~s}$. The vibration platform creates multidirectional vibrations $[10,11]$ in the horizontal plane, but in the form, natural vibrarations of the system arise, forming the vertical components of vibrations.

The vibration platform has several possible modes of vibrations created by alternately turning on the motors of an electronic circuit automatically or using manual control and having the following character (Fig. 2).

As a result, the vertical formwork surfaces simultaneously perceive identical, normal dynamic impulses for them, and, consequently, all vertical walls of a volume product receive the same degree of compaction due to the offset of the unbalance shaft of the exciter relative to the center of gravity of the form. It increases the vertical components of the amplitude of the vibration displacement, which allows compacting the products

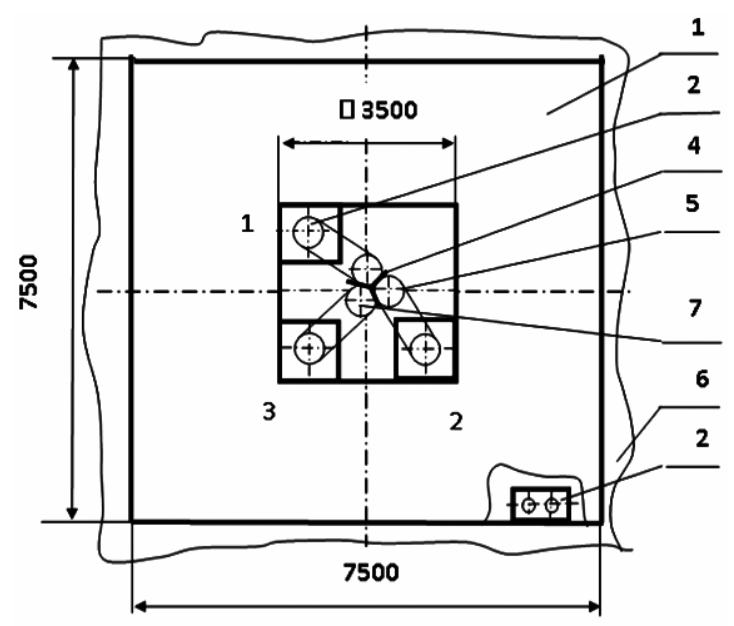

Fig. 1. Vibration platform with a load capacity of $60 t$ with a variable vibration mode

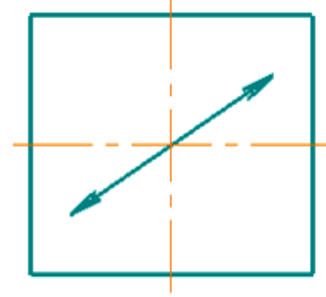

$a$

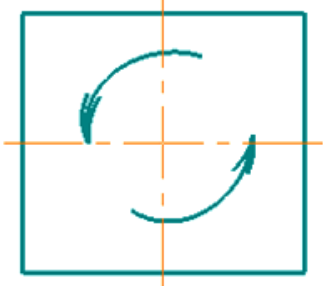

$b$

effectively without additional inclination of the vibration generator.

Depending on the weight of the compacted product, a change in the force of the vibration generator is possible [12, 13]. At the same time, the most effective in the technical aspect of transverse vibrational movement of the frame is provided by synchronizing two vibration generators.

The main dynamic and consumer benefits of a vibration generator with vertical debalanced shafts are the following

With such an arrangement of debalances, forces do not work against gravity for each period of vibration and, therefore, for the most part perform a useful work on creating and overcoming inertial forces of the vibration system. In this case, the drive motor is more evenly distributed, which reduces its installed capacity.

Vibrating generators with a vertical shaft require significantly less time and starting power to accelerate to a frequency of constant vibrations, so that in the electrical network, the current is supplied to the drive motor, the jump of the starting current will be less long [4]. To simplify the calculations of the mathematical model, we make some assumptions:

1) we consider the work of two vibration generators;

2 ) we consider the third vibrator as the one that does not affect the movement of the working body of the vibration platform.

To describe the motion of a body, we introduce two coordinate systems: a moving system of rectangular coordinates hardness connected to the body $\bar{O} \overline{x y z}$, the beginning of which we will combine with the center of mass of the body, the axis $\bar{O} \bar{x}$ and $\overline{O y}$ will be placed in the longitudinal and transverse planes symmetry of the body, and the axis $\bar{O} \bar{z}$ will be directed to the vertical and inertial (stationary) coordinate system $\bar{O} \bar{z}$, which we choose so that in the position of the static equilibrium of the body, the axes of the two systems coincide. The position of the body in the inertial coordinate system is determined by the three coordinates of its center of mass $x 0, y 0, z 0$ and by three angles $\theta, \eta, \psi$ of the body rotation relative to the axes $O x, O y$ and $O z$.

As a result, for the simplified model, considered with the symmetry of the location of elastic supports and the vibration generator, we obtain the following differential equations of body motion in the form of the Lagrange equations of the second kind

$$
\begin{gathered}
M \ddot{y}_{0}+C_{22} \cdot y_{0}+C_{24} \cdot \theta=\sum_{K=1}^{m} F_{y} ; \quad M \ddot{z}_{0}+C_{33} \cdot z_{0}=\sum_{K=1}^{m} F_{z} ; \\
J_{x} \ddot{\theta}+C_{42} y_{0}+C_{44} \theta=\sum_{K=1}^{m} F_{z} \cdot \bar{y}_{b K}-\sum_{K=1}^{m} F_{y} \cdot \bar{Z}_{b K} ; \\
J_{y} \ddot{\eta}+C_{51} x_{0}+C_{55} \eta=\sum_{K=1}^{m} F_{x} \cdot \bar{Z}_{b K}-\sum_{K=1}^{m} F_{z} \cdot \bar{x}_{b K} ;
\end{gathered}
$$

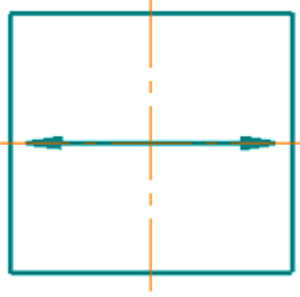

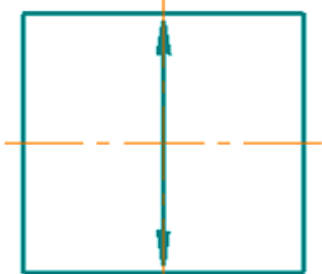

Fig. 2. Types of vibrations:

$a$ - diagonal vibrations - achieved by simultaneously turning on the electric motors 1 and 2 (Fig. 1), the electric motor 3 - is turned off; $b$ - torsional vibrations - electric motors 2 and 3 are working, with the electric motor 3 operating in the reverse mode, the electric motor 1 being off; $c$ transverse vibrations - created by electric motors 3 and 1, electric motor 2 -off; $d$-longitudinal vibrations - electric motors 2 and 3 are working at the same time, electric motor 1 is off 


$$
J_{x} \ddot{\psi}+C_{66}=\sum_{K=1}^{m} F_{y} \cdot \bar{x}_{b K}-\sum_{K=1}^{m} F_{x} \cdot \bar{y}_{b K},
$$

where $M$ is the mass of the body; $J x, J y, J z$ are moments of the body inertia relative to the axes $O x, O y, O z ; x 0, y 0, z 0$ are vibrational displacement of the body mass center in a fixed coordinate system $O x y z ; C 11 \ldots C 66$ are hardness coefficients of the elastic support of the suspension; $\bar{X}_{b K}, \bar{Y}_{b K}, \bar{Z}_{b K}$ are coordinates of point B of the application of the forced force of the $K^{\text {th }}$ vibrator $(K=1 \ldots m) ; m$ is the number of vibration generators $(m=2)$.

The hardness coefficients of the elastic suspension with a symmetrical arrangement of the elastic supports and at the same distance in height relative to the center of mass are

$$
\begin{gathered}
C_{11}=r C_{x} ; \quad C_{22}=r C_{y} ; \quad C_{33}=r C_{z} ; \\
C_{44}=C_{22} \cdot \bar{Z}_{A}^{2}+C_{33} \bar{y}_{A}^{2} ; \quad C_{55}=C_{11} \cdot \bar{y}_{A}^{2}+C_{y} \sum_{S=1}^{n} X_{A S}^{2} ; \\
C_{15}=C_{51}=C_{11} \bar{Z}_{A} ; \quad C_{4}=C_{42}=-C_{22} \bar{Z}_{A},
\end{gathered}
$$

where $C_{x}, C_{y}, C_{z}$ are components of the hardness of the elastic support behind the coordinate axes $O x, O y, O z ; \bar{x}_{A S}, \bar{y}_{A S}$, $\bar{z}_{A S}$ are the corresponding coordinates of the support hardness center $(S=1 \ldots r) ; r$ is the number of elastic supports.

Due to the symmetry of the location of elastic supports centers in the general horizontal plane we denote $\bar{y}_{A S}=\bar{y}_{A}$; $\bar{z}_{A S}=\bar{z}_{A}$.

The origin of the debalance rotation angle of $\varphi \mathrm{K}$ generator is selected from the position of the static equilibrium of its center of mass. With the vertical arrangement of the axes of $x \times$ debalance rotation, when their centers of mass do not occupy certain positions under the influence of weight force, the angles $\varphi \mathrm{K}$ will be deducted from the horn and axis $O h$. Determine the basic dynamic and constructive parameters of the vibration platform (Fig. 3)

Constructive scheme is chosen according to Fig. 3 as the most optimal for the formation of these products. On this basis, we establish the overall dimensions of the vibration platform and calculate the mass of all the constituent elements.

Determine the mass of the form, $\mathrm{kg}$

$$
M_{f}=V \cdot \rho_{0} \cdot S \cdot \frac{\rho_{m}}{1000},
$$

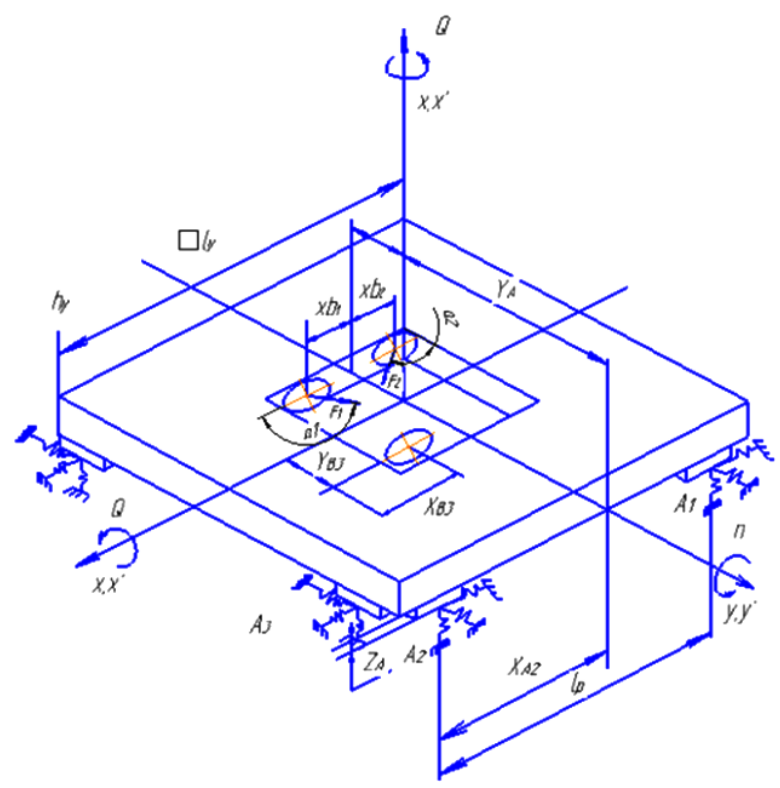

Fig. 3. Dynamic model of vibration platform with two simultaneously operating vibration generators where $V$ is the volume of concrete mix, calculated according to the proposed drawing (for twenty products $V=1.339 \mathrm{~m}^{3}$ ); $\rho_{0}$ is the average density of concrete mix, we accept $\rho_{0}=2400 \mathrm{~kg} / \mathrm{m}^{3}$; $S$ is formwork area encountering the surface of the product, for two products $S=1.03 \cdot 20=20.6 \mathrm{~m}^{2} ; \rho_{m}$ is the specific metal content, equal to $12 \mathrm{~kg} /\left(\mathrm{t} \cdot \mathrm{m}^{2}\right)$, it is determined by the formula

$$
M_{f}=1.339 \cdot 2400 \cdot 20.6 \cdot \frac{12}{1000}=794 .
$$

Determine the appropriate vibration set for the given loadcarrying capacity. Weight of the form with the products is, $\mathrm{kg}$

$$
M_{S}=M_{F}+2 \cdot M_{P},
$$

where $M_{F}$ is the mass of the form, $\mathrm{kg}, M_{P}$ is the mass of the product.

$$
M_{S}=794+(50 \cdot 20)=1794 .
$$

Choose a vibration set. Then the weight of the vibroform, equipped with the vibration set, is $\mathrm{kg}$

$$
M_{P . F .}=794+50=844 .
$$

Then the total mass of vibration form together with the product is, $\mathrm{kg}$

$$
M_{T}=M_{P . F .}+M_{S},
$$

where $M_{P . F}$ is the weight of the form with the product; $\mathrm{kg}, M_{T}=$ $=844+(50 \cdot 20)=1844$.

Determine the mass of vibrating parts, $\mathrm{kg}$

$$
\begin{gathered}
M_{P . D .}=\left(M_{P . F .}+M_{S}\right) \cdot k_{1} ; \\
M_{P . D .}=(844+1794) \cdot 0.625=1648.75 .
\end{gathered}
$$

Accept the angular velocity of the vibration generator shaft equal to $\omega=150 \mathrm{rad} / \mathrm{s}$.

We determine, depending on the technological features and the time of vibration effect, the amplitude of the horizontal vibration displacement from the condition $A \cdot \omega^{2}=$ $=(2.0 \ldots 2.5)$. We accept, proceeding from the condition, the amplitudes of transverse vibro displacements equal to $0.001 \mathrm{~m}$ and longitudinal equal to $0.0005 \mathrm{~m}$.

Determine the magnitude of the vibrational generator force, $\mathrm{H}$

$$
F=k_{2} \cdot M_{P . D .} \cdot A \cdot \omega^{2},
$$

where $k_{2}$ is the coefficient of proportionality equal to beam type products $-0.24 ; A$ is the geometric amplitude of horizontal vibro displacement, determined by the formula

$$
A=\sqrt{A_{x}^{2}+A_{y}^{2}},
$$

where $A_{x}$ is longitudinal vibrational displacement, $\mathrm{m} ; A_{u}$ is transverse vibrational displacement, $\mathrm{m}$.

$$
\begin{gathered}
A=\sqrt{0.0005^{2}+0.001^{2}}=0.0011 ; \\
F=0.24 \cdot 30201 \cdot 0.0011 \cdot 150^{2}=179394 .
\end{gathered}
$$

Longitudinal vibrational displacement, $\mathrm{m} ; A u$ is transverse vibrational displacement, $\mathrm{m}$

$$
N_{l}=k_{\omega} \cdot M_{P . D .},
$$

where $k_{\omega}$ is the proportionality coefficient equal to $0.5 \mathrm{~W} / \mathrm{kg}$; $N_{y}=0.5 \cdot 1648=824$.

We accept the power of the drive to be $15.1 \mathrm{~kW}$.

Specification of the electric motor power

$$
N_{y}=\frac{F^{2} \cdot k}{\pi \cdot \omega \cdot M_{P . D .}}+F \cdot f \cdot \frac{d}{2} \cdot \omega,
$$


where $f$ is the rolling friction coefficient of roller bearings, equal to $0.006-0.008 ; d$ is the internal diameter of bearings equal to $0.13 \mathrm{~m}$.

Determine the number of elastic supports

$$
n_{0}=\frac{\left(M_{P . F .}+M_{S}\right)}{Q_{0}}
$$

where $Q_{0}$ is calculated load of one elastic support, $\mathrm{kg}$.

Determine the allowable hardness, $\mathrm{H} / \mathrm{m}$, of one elastic rubber-metal support in the horizontal plane to ensure resonant mode of vibration

$$
C_{X Y}=\frac{\left(M_{P . F .}+M_{S}\right) \cdot \omega^{2}}{12 \cdot n_{0}} ; C_{X Y}=\frac{(24123+24200) \cdot 150^{2}}{12 \cdot 10}=9.1 .
$$

The result $n_{0}$ is determined to the even number towards a higher level. We accept elastic support OU-6 in the amount of 10 pieces

\section{Conclusions.}

1. The theoretical dependencies that allow us to establish the rational parameters of the vibration platforms for the formation of large-sized massive reinforced concrete products are obtained.

2. The carried out mathematical modeling allows determining the rational parameters of each vibration generator to ensure a given vibration amplitude of the vibration platforms, which is set in motion by three vibrating generators with a pairwise alternate activation according to the mode of operation.

3. The proposed theoretical dependencies are the basis for the development and design of vibration platforms with debalanced circular vibration generators.

\section{References.}

1. Olehnovich, K.A., Vinogradov, Yu. I., \& Nesterenko, N.P. (1991). Performance of modern vibrating plate compactors. Construction and road building machinery, (8), 14-16.

2. Orlovskiy, V. M., Savyk, V.M., Molchanov, P. O., \& Pohilko, A.S. (2018). Lightweight plugging material. Naukovyi Visnyk Natsionalnoho Hirnychoho Universytetu, 4, 36-42. DOI: 10.29202/nvngu/2018-4/2.

3. Korobko, B. O. (2016). Investigation of energy consumption in the course of plastering machine's work. Eastern-European Journal of Enterprise Technologies (Energy-saving technologies and equipment), 4(8(82)), 4-11.

4. Nesterenko, M., Nazarenko, I., \& Molchanov, P. (2018). Cassette installation with active working body in the separating partition. International Journal of Engineering and Technology (UAE), 7(3), 265-268. DOI:10.14419/ijet.v7i3.2.14417.

5. Solovjov, V. V., \& Roy, N. N. (2015). Investigation of strainstress state round the borehole massif containing the plastic rocks. Metallurgical and mining industry, (8), 555-558.

6. Chen, X., Wu, S., \& Zhou, J. (2013). Experimental study and analytical formulation of mechanical behavior of concrete. Construction and Buildings Materials, 47, 662-670.

7. Nesterenko, M.P. (2015). Progressive development of equipment with spatial oscillations for forming concrete products. Academic journal. Industrial Machine Building, Civil Engineering. Poltava: PoltNTU, 2(44), 16-23.

8. Biletskyi, V., Molchanov, P., Sokur, M., Gayko, G., Savyk, V., Orlovskyy, V., ... \& Fursa, R. (2017). Research into the process of preparation of Ukrainian coal by the oil aggregation method. Vostochno - Evropeyskiy zhurnal peredovyih tehnologiy, 3(5(87)), 45-53.

9. Babakov, I.M. (2004). Theory of the oscillations. Moscow: Drofa (pp. 343-364).

10. Sivko, V.Y., Yakovenko, V.B., \& Mischuk, E. O. (2015). Research modes of vibration compaction of concrete in the cartridge units. Tekhnika budivnytstva, (34), 30-34.
11. Biletskyi, V.S., Shendrik, T., \& Sergeev, P. (2012). Derivatography as the method of water structure studying on solid mineral surface. In Geomechanical Processes During Underground Mining. CRC Press Taylor \& Francis Group, London, UK. A BalkemaBook (pp. 181-184). Retrieved from http://www.crcnetbase.com/doi/abs/10.1201/b13157-31.

12. Maslov, O. G., Serbin, V. O., \& Luk'yanenko, V. P. (2015). Defining the rational parameters of an oscillating machine to form concrete blocks. Scientific Journal "Transactions of Kremenchuk Mykhailo Ostrohradskyi National University", 1(90(1)), 98-103.

13. Sokur, N., Biletskyy, V., Sokur, L., Bozyk, D., \& Sokur, I. (2016). Investigation of the process of crushing solid materials in the centrifugal disintegrators. Eastern-European Journal of Enterprise Technologies, 3(7(81)), 34-40.

\section{Вібромайданчики для формування великорозмірних об'ємних залізобетонних виробів}

\section{М. П. Нестеренко, П. О. Молчанов, В. М. Савик, М.М. Нестеренко}

Полтавський національний технічний університет імені Юрія Кондратюка, м. Полтава, Україна, e-mail: mpnesterenko@ukr.net; petja_men@ukr.net

Мета. Розробка математичної моделі вібраційної установки для формування великорозмірних об'ємних залізобетонних виробів.

Методика. Теоретичні дослідження грунтувалися на використанні класичної теорії коливань механічних систем, суцільних середовищ і прикладної механіки. Для аналізу математичних моделей використовувалися аналітичні й чисельні методи з використанням ПЕОМ.

Результати. За допомогою математичного дослідження просторового руху робочого органу розроблена динамічна модель вібромайданчика у вигляді твердого тіла, що спирається на пружні опори. Вібромайданчик приводиться в рух за допомогою трьох віброзбуджувачів, що попарно почергово вмикаються за заданим режимом роботи. Крім того, запропонована система електроприводу за схемою одночасної почергової роботи двох віброзбуджувачів, що поєднує в собі позитивні властивості класичної системи приводу вібраційних машин з поліпшеними показниками ефективності формування великорозмірних об'ємних залізобетонних виробів. Отримані диференціальні рівняння, що дозволяє визначити параметри кожного з віброзбуджувачів коливань для забезпечення заданої амплітуди коливань вібромайданчика.

Наукова новизна. Одержана динамічна модель вібростенда, що опирається на пружні опори та приводиться в рух за допомогою трьох віброзбуджувачів з попарним почерговим їх увімкненням за заданим режимом роботи.

Практична значимість. Визначені раціональні параметри кожного із трьох віброзбуджувачів коливань для забезпеченя заданої амплітуди коливань вібромайданчика.

Ключові слова: віброзбуджувач, вібромайданчик, дебаланс, математична модель, пружна опора, бетонна суміш

\section{Виброплощадки для формования крупноразмерных объемных железобетонных изделий}

\section{Н. П. Нестеренко, П.А. Молчанов, В. Н. Савик, Н. Н. Нестеренко}

Полтавский национальный технический университет имени Юрия Кондратюка, г. Полтава, Украина, е-mail: mpnesterenko@ukr.net; petja_men@ukr.net 
Цель. Разработка математической модели вибрационной установки для формирования крупноразмерных объемных железобетонных изделий.

Методика. Теоретические исследования основывались на использовании классической теории колебаний механических систем, сплошных сред и прикладной механики. Для анализа математических моделей использовались аналитические и численные методы с использованием ПЭВМ.

Результаты. С помощью математического исследования пространственного движения рабочего органа разработана динамическая модель виброплощадки в виде твердого тела, опирающегося на упругие опоры. Виброплощадка приводится в движение с помощью трех вибровозбудителей, которые попарно поочередно включаются по режиму работы. Кроме того, предложена система электропривода по схеме одновременной последовательной работы двух вибровозбудителей, сочетающая в себе положительные свойства классической системы привода вибрационных машин с улучшенными показателями эф- фективности формирования крупноразмерных объемных железобетонных изделий. Полученные дифференциальные уравнения позволяют определить параметры каждого из вибровозбудителей колебаний для обеспечения заданной амплитуды колебаний виброплощадки.

Научная новизна. Получена динамическая модель вибростенда, опирающегося на упругие опоры, который приводится в движение с помощью трех вибровозбудителей с попарным поочередным их включением согласно с режимом работы.

Практическая значимость. Определены рациональные параметры каждого из трех вибровозбудителей колебаний для обеспечения заданной амплитуды колебаний виброплощадки.

Ключевые слова: вибровозбудитель, виброплощадка, дебаланс, математическая модель, упругая опора, бетонная смесь

Рекомендовано до публікації докт. техн. наук Ю. Л. Ванниковим. Дата надходження рукопису 21.11.18. 